\title{
Liquidity and Off-Balance Sheet Items: A Comparative Study of Public and Private Sector Banks in India
}

\author{
N. Pushkala', J. Mahamayi ${ }^{2}$ and K. A. Venkatesh ${ }^{3}$ \\ ${ }^{1}$ Research Scholar, Madurai Kamaraj University and AP, NMKRV College for Women, India \\ ${ }^{2} \mathrm{AP}$, Department of Commerce, VVV College for Women, Virudhunagar, India \\ ${ }^{3}$ Professor of Math and Computer Science, Presidency University, Bangalore, India
}

\begin{abstract}
Liquidity is the life-line of every business. Banking business' liquidity was the bone of contention during the economic crisis of Greece and the downfall of Finance Behemoth like Lehman Brothers. Banking SectorIlliquidity was the epicentre of such crisis. Globally, the Off-Balance Sheet Exposure played a vital role in managing liquidity and solvency issues of commercial banks. This research paper explores the concepts, aspects, analysis of liquidity and the impact of Off-Balance Sheet Items on Liquidity and Solvency. Furthermore, this paper focuses on the liquidity aspects of Public and Private Sector banks towards scrutinizing whether the ownership has any influence on the liquidity and solvency aspects of the banking structure, under the backdrop of Off-Balance Sheet Exposure. Besides, it looks into the unpredictability of RBI's policies on liquidity like Cash Reserve Ratio, Statutory Liquidity Ratio etc.
\end{abstract}

Keywords: Liquidity, Off-Balance Sheet items, Deposits, Risk, Liquidity and Solvency Ratios

\section{Introduction}

The Banking Sector is a very important financial intermediary in tapping savings and transforming them into consequent investments. Such a process requires due diligence towards ensuring profitable investments of such savings, to honour, safeguard and return the savings in due course with appropriate returns thereon. Hence, Liquidity and Solvency are inseparable attributes of a successful banking business. The Liquidity of banks depends on the banks' ability to pay off its liabilities and to timely discharge of their obligations. Liquidity crunch arises when the deposits are demanded and the bankers fail to honour their commitments to repay the same. Asset-Liability mismatch in the period of maturity leads to liquidity risk, resulting in solvency.
With the reinforcement of prudential norms of Banking International Settlements, Basel, Switzerland, including but limited to Basel-III norms-all aspects of bank management like liquidity, capital adequacy, solvency and profitability have been dealt with inflexibility towards ensuring that the banks are sufficiently insulated to absorb the global economic shocks like fall of Lehman Bros, US Federal Policy Changes, Brexit or Bremain etc. Hence Basel - III norms focussed more on managing and controlling risk exposure by assigning weights, introducing more stringent liquidity ratios and laid benchmarks in attaining capital adequacy ratio.

Although Indian banks are heavily insulated from global shocks due to compliance to prudential norms of RBI, as introduced from time to time, the government-owned commercial banks [Public Sector Banks]

*Email: prof.kavenkatesh@gmail.com 
always took shelter under the liquidity cover [ in the form of repos]. Hitherto, there are lots of constraints in terms of the Non-performing Assets they carry in their books. The Public Sector Banks loaded with heavy substandard assets, initiate substantial provisioning which in turn triggers huge losses that are consequently reported in their balance sheets. The enormousness of provisioning for NPAs is never disclosed in financial statements of commercial banks in India. Thus said, such huge provisions result in losses to the commercial banks and eats into exchequer-reserves.

Theoretically, the liquidity crisis manifests when the banks fail to honour their financial commitments, as appearing in the Balance Sheet. But, as history has time-and-again revealed, the Off-balance Sheet commitments like binding Forward Exchange Contracts and Guarantees contributed to the downfall of universal banks in the U.S. Such OBS items pose unwarranted threat to the very existence of the banks, in terms of weak solvency base. Basel-II norms assigned weights to Off-balance Sheet items and made Capital Adequacy norms- compliance mandatory. Basel-III norms make the Indian banking regulator, RBI to implement them gradually over the next few years (before 2019) and also to make the Indian commercial banks to "clean up" the balance sheet with due write-off of NPAs. Capital Infusion into Public sector banks is also on discussion in the corridors of power of Indian Government. Being the Lender of Last Resort, RBI supplies funds to all commercial banks through its repo system.

This paper discusses the liquidity aspects of commercial banks from the micro economic perspective without focusing on macroeconomic aspects. The study reveals the liquidity of both public and private sector banks in general and on the liquidity risk in the context of Off-balance sheet items in particular. Since the foreign banks in India meet their liquidity needs from their parent banks, incorporated outside India, they are kept outside the purview of this research. The public sector and private sector banks in India are under strict surveillance of the RBI and their fund-requirements are also taken care by RBI to the maximum extent feasible. Hence the liquidity as a core factor for these banks is being studied in detail, which is as follows:
- To assess the liquidity of Private and Public Sector banks in India.

- To explore the relevance of the concepts of Liquidity, Solvency and Off-balance Sheet items to the banking sector.

- To ascertain the level of liquidity and solvency of Private and Public sector banks in India.

- To measure the impact of Off-balance Sheet items on the liquidity of Private and Public Sector banks in India.

Off-Balance Sheet items are those which appear as footnotes on the balance sheets of commercial banks. They are neither the assets nor the liabilities. In other words, revenue by way of fees constitutes assets and once the OBS items turned out to be the failed contracts, they become the obligations. Sub-prime crisis in US happened due to such Mortgage-based derivatives transforming themselves into liabilities. Thus said, the Basel norms became more stringent and Riskweights are assigned to these off-balance sheet items and Capital Adequacy Ratio is accordingly, computed. Thus, it leads one to believe that the OBS items determine the solvency and liquidity of a bank on one side and on the other, they contribute towards profitability of the banks up to $12 \%$.

The decline in the interest rates, led to a fall in the interest revenue, the major source of income to the banks, thus, depleting the profits. Entry of foreign banks and private banks made the Indian banks to take recourse to universal banking. In turn, fee-based services yielded income in the form of Guarantee commission and Forward Exchange Contract Premium contributing to the steady flow of income to the commercial banks. It had a direct impact on the fall in revenue due to condensed traditional interest income. Though the profitability has improved on account of these OBS items, they equally carry the probability of manifestation of Liquidity and Solvency Risks.

Although much research works have been carried away in the area of OBS items and their impact on profitability of commercial banks, there is very little attention given to liquidity aspects of OBS items. This paper focuses on OBS components and its impact on

SDMIMD Journal of Management | Print ISSN: 0976-0652 | Online ISSN: 2320-7906 
Liquidity and Solvency of Public and Private sector banks minutely!

\section{Review of Literature}

In the light of the adoption of the Basel - III norms, the liquidity-defining ratios like Liquidity Coverage Ratio and Net Stable Funding Ratio were widely discussed and a new Liquidity ratio, Liquidity Stress Ratio (LSR) was used to analyse cross-sectional data among smaller number of banking-holding companies in the US. The findings revealed that the stress ratios reveal the early warning signals on liquidity crisis. The findings also established that there is no correlation between Return on Assets (ROA) and LSR. (Dong Beom Choi \& Lily Zhon, 2014).

The study on Liquidity and Profitability Analysis of Commercial Banks in India - focused on the overall performance of commercial banks in India. They concluded that ownership pattern had influenced the liquidity and profitability of public sector banks and private and foreign banks have improved on the same. (Urmila Bharathi et al; 2014)

Anamika Singh et al; (2016), in their study found that foreign banks and private banks did not face any liquidity crunch due to the existence of adequate reserves in their books. They found that bank size has an adverse liquidity impact and that higher CAR has a positive influence on liquidity of commercial banks in India.

The Study on Liquidity Management of Public Sector Banks analysed the liquidity ratios and found that the liquidity position of these banks had a steep decline during the period of study [2010-13] drastically and the reasons are frequent changes in the credit policy of RBI. (A. S. Ramanarayanan et al;).

Anitha Makkar \& et al; (2013) applied statistical techniques and found that there is significant difference in the Capital Adequacy, Asset Quality and Earning Capacity of Public and Private Sector Banks in India, whereas there is no significant difference in the Management, Liquidity Position and Degree of Sensitivity to the Market Risk of the banks.

http://www.informaticsjournals.com/index.php/sdmimd | Vol 8 | Issue 1 | March 2017
The study titled 'An Empirical Analysis of the Off-balance Sheet Activities of Indian Banks (Dilip Nachane \& Sailbal Ghosh, 2007), dealt with the factors influencing OBS items and concluded that regulatory factors influenced the OBS activities to a great extent for foreign banks.

PushkalaNarasimhan et al; studied the effect on OBS items on the profitability of foreign banks in India [2016] and explored the concept of OBS Exposure and their impact on profitability of foreign banks. They found that the foreign banks make huge provisions to face OBS risk and their contribution as Non- interest income from $20-22 \%$ to the total profits.

Diana Teixeira (2013) investigated the impact of Offbalance Sheet Items on the Credit Risk Taking and Liquidity-Seeking Behaviour of European Banks. They concluded that the motives of OBS are not based on risk transfer and they did not have statistically significant relationship with the liquidity of the banks. Cheenu Goel \& Chitwan Bhutani Rekhi (2013) studied the performance of the select public and private sector banks in India by using various ratios. They found that efficacy and profitability are interrelated and the public sector banks failed to perform on the given parameter. It is the same case with private sector banks too, though they are stronger on various financial and structural aspects.

\section{Methodology}

In this research, secondary data from the RBI website were extensively used to explore the objectives of the study in detail. Magazines, Journals and Commercial Newspapers are the major source of secondary data herein. Ratio analysis has been used as the major tool of in-depth analysis and the data are considered from 2011 to 2015, towards achieving the objectives of the study. Armed with a thorough look into the liquidity and solvency aspects of public and private sector banks, this research also studied, in detail, the impact of OBS items on the performance-determining attributes of the commercial banks. The various ratios used in the study are given in the following table. 


\section{Limitations of the Study}

This study focused only on the Private and Public Sector banks in India, but not on the Foreign Banks and the Regional Rural Banks. The data available are only from secondary resources. The individual bank's balance sheets are not utilised to conduct an in-depth study of the liquidity aspects of the banks in detail. Therefore, this study may not reveal the true liquidity conditions of banks in particular.

\section{Liquidity of Commercial Banks in India}

Liquidity and Solvency are the basic yet critical aspects of performance- evaluation of commercial banks. Although Indian banks are being regulated well in ensuring adequate liquidity, through controls like Cash Reserve Ratio (CRR) and Statutory Liquidity Ratio (SLR) for a very long time, the Commercial Banks in India face the issue of lack of liquidity for other reasons like poor management of Asset and Liabilities mismatch. Parameters like Duration and Duration Gap have not really delivered towards a more effective liquidity management. Moreover the caprices of the weather and lack of political will in the areas of priority lending like agricultural loans led to huge gap in recovery. It resulted in mounting low quality assets.

\subsection{Liquidity Rules as Per Legal Requirements}

- Under section 42 of the RBI Act, 1934, the commercial banks have to keep a certain minimum reserve with RBI called Cash Reserve Ratio (CRR) which is not less than $3 \%$ and not exceeding $15 \%$ of total Net Demand and Time Liabilities (NDTL)

- Under section 24 of the Banking Regulations Act, 1949, every commercial bank has to maintain liquid assets in the form of cash, gold and gilt-edged securities - Statutory Liquidity Ratio (SLR) which is not less than $25 \%$ and not more than $40 \%$ of NDTL.

\section{Liquidity Ratios}

\subsection{Credit - Deposit Ratio}

The Loans to Deposit ratio is a commonly used tool for measuring a bank's liquidity position. It is done by calculating the ratio between total loans of the banks and their total deposits. An unduly high ratio is indicative of sufficient liquidity to meet the requirements and a relatively low ratio, will have an adverse impact on the profitability of the banks.

The above table reveals that private banks consistently maintained a healthy ratio and no significant variations were noticed. Public Sector banks have a high level of deposits. As public sector banks are known for high priority sector lending, this ratio shows an increasing trend. Interestingly, the overall loan-deposit ratio of all commercial banks came down drastically to $74 \%$ due to greater fall in credit growth rate as compared to the decline in deposit growth for the same period.

\subsection{Liquid Assets to Demand Deposits Ratio}

Demand Deposit is the first line of liquidity to be honoured by banks. These deposits demand high liquidity or immediate payment of funds without any delay. The basic tenets of banking, 'payable on demand' are the first order of liquidity. Hence, the cash and cash equivalents should be sufficient to honour demand liabilities.

The above table reveals that the private banks enjoy higher liquidity ratios vis-à-vis those of the Public Sector Banks. Huge levels of Cash and Cash Equivalents mean that the Private Sector Banks rely on robust liquidity to meet all contingencies on time. In the case of Public Sector Banks, the unduly high levels of ill-performing

Table 1

\begin{tabular}{ccc}
\hline Year & Private Sector Banks & Public Sector Banks \\
\hline 2011 & 75.57 & 79.53 \\
2012 & 77.51 & 82.28 \\
2013 & 77.85 & 81.90 \\
2014 & 77.42 & 84.37 \\
2015 & 76.11 & 86.36 \\
\hline
\end{tabular}

Table 2

\begin{tabular}{ccc}
\hline Year & Private Sector Banks & Public Sector Banks \\
\hline 2011 & 28.8828 & 0.900883 \\
2012 & 140.3376 & 0.80546 \\
2013 & 84.48076 & 0.695765 \\
2014 & 65.50902 & 0.843382 \\
2015 & 0.5103 & 0.894779 \\
\hline
\end{tabular}


assets have resulted in a mismatch of timing of assetrealisation and liability-discharge. Public Sector Banks depend heavily on RBI for liquidity support through repo transactions.

\subsection{Liquid Assets to Total Assets Ratio}

Liquidity concerns for a bank originate from both the sides of the Balance Sheet for a Commercial Bank. Mismatch in duration of asset-liability coupled with an increasing demand for loans puts heavy pressure on the liquidity management processes of commercial banks. Hence higher the ratio, greater is the comfort of the bank in meeting its timely obligations.

From the above table it is discernible that there is no significant change in the liquidity performance of both the banks. But the ratios are low given that they range from 0.06 to 0.04 for these banks. Not the least encouraging.

\subsection{Liquid Assets to Total Deposits Ratio}

Total Deposits include both, time and demand liabilities. Any unprecedented rumour of banks' solvency will create panic amongst the deposit holders prompting them to withdraw their deposits. The risk of a "run on the bank' will be eminent.

The Liquid Assets to Total Deposits Ratio of the banks, as analysed above reveals that both the sectorial banks are

Table 3

\begin{tabular}{ccc}
\hline Year & Private Sector banks & Public Sector Banks \\
\hline 2011 & 0.066641 & 0.069788 \\
2012 & 0.048655 & 0.051262 \\
2013 & 0.047123 & 0.046848 \\
2014 & 0.049056 & 0.048982 \\
2015 & 0.048736 & 0.051052 \\
\hline
\end{tabular}

Table 4

\begin{tabular}{ccc}
\hline Year & Private Sector Banks & Public Sector Banks \\
\hline 2011 & 0.100254 & 0.084497 \\
2012 & 0.070134 & 0.061885 \\
2013 & 0.067175 & 0.054367 \\
2014 & 0.069617 & 0.059236 \\
2015 & 0.069093 & 0.061576 \\
\hline
\end{tabular}

not equipped to pay all the deposit holders, in time. When evaluated against the Liquid Assets to Demand Deposits ratios as in Para 2, which by themselves are satisfactorily high, this Liquid Assets to Total Deposits Ration reveals that the time liability is very high in proportion.

\subsection{Government Securities to Total Assets}

Investment in Government Securities as a per cent of deposits is a mandatory norm for all banks in India. Though it facilitates high liquidity and generates a fixed income to the commercial banks, it is beset with a few challenges. If the credit demand fails to take off, the banks would increase their investment in government securities. Though other investments in corporate securities are also allowed, government securities are the favourite investment destination for all the commercial banks.

From the data presented above, it is found that both the sectorial banks maintained consistent ratios for the period from 2011 to 2015. Only in 2014, did the Public Sector Banks reduce their investments to an unbelievably low level.

\subsection{Demand Deposits to Total Deposits}

As the ratios related to deposits discussed earlier, this ratio clearly outlines the need for maintaining liquid assets. Time Liabilities include fixed deposits, recurring deposits, savings bank deposits etc. Demand Liabilities are liabilities which are payable on demand.

Table 5

\begin{tabular}{ccc}
\hline Year & Private Sector Banks & Public Sector Banks \\
\hline 2011 & 0.206932 & 0.202974 \\
2012 & 0.204844 & 0.20739 \\
2013 & 0.205149 & 0.213192 \\
2014 & 0.186247 & 0.052414 \\
2015 & 0.189745 & 0.199459 \\
\hline
\end{tabular}

\begin{tabular}{ccc}
\hline Year & Private Sector Banks & Public Sector Banks \\
\hline 2011 & 0.293367 & 0.077467 \\
2012 & 0.22703 & 0.063644 \\
2013 & 0.225635 & 0.067333 \\
2014 & 0.20488 & 0.058078 \\
2015 & 0.190396 & 0.057056 \\
\hline
\end{tabular}

SDMIMD Journal of Management | Print ISSN: 0976-0652 | Online ISSN: 2320-7906 
The outcome of above analysis is that the Private Banks has about $25 \%$ of total deposits as demand deposits whereas the Public Sector Banks have a higher component of time liabilities. Hence the Private Sector Banks maintain a larger component of heavy liquid funds to meet demand deposits as compared to their Public Sector counterparts

\section{Solvency of Commercial Banks in India}

The liquidity mismanagement of commercial banks in the long run results in solvency crisis all over the world. Big banks like Lehman Bros in U.S failed due to liquidity crisis over the Off-balance sheet items like derivatives. Such failures shake the financial system and loop the systemic risk to dangerous levels. Short term solvency risk arises out of liquidity mismanagement. Hence this paper reconnoitred in a detailed manner the solvency aspects of commercial banks in India.

\subsection{Capital Adequacy Ratio (CAR)}

A bank's CAR is the ratio of qualifying capital to risk adjusted or weighed assets. Capital Adequacy ratio under Basel -III norms is being implemented in India in the coming years:

Table 6

\begin{tabular}{cc}
\hline Year & CAR \\
\hline 2016 & $9.62 \%$ \\
2017 & $10.25 \%$ \\
2018 & $10.87 \%$ \\
2019 & $11.5 \%$ \\
\hline CAR = Tier I + Tier II + Tier III [capital funds]/Risk \\
weighted assets
\end{tabular}

\section{Capital Adequacy Ratios of Commercial Banks}

Table 7

\begin{tabular}{ccc}
\hline Year & Public Sector Banks & Private Sector Banks \\
\hline 2011 & $13.1 \%$ & $16.1 \%$ \\
2012 & $13.2 \%$ & $16.2 \%$ \\
2013 & $12.4 \%$ & $16.8 \%$ \\
2014 & $11.2 \%$ & $13.1 \%$ \\
2015 & $11.24 \%$ & N.A \\
\hline
\end{tabular}

The loans assets as they appear in balance sheet of the banks are assigned weights of risk and off-balance sheet items are also given risk weights. Hence the CAR is of highly authentic ratio of solvency. The gradual decline of CAR poses serious questions on capital inadequacy to meet the risky obligations and loan failures. Potential Non-performing Assets and their mandatory provisioning made the Indian Public Sector Banks to infuse fresh capital to the tune of around Rs.1,00,000 Crore.

\subsection{Equity Capital to Total Assets}

The Equity Capital in normal business tends to have considerable match with long-term assets. However, the commercial banks should not have such match of Equity Capital to Total Assets. The commercial banks in India have this ratio at dangerously low level.

With Basel-III norms redefining the parameters for computing CAR, the Public and Private Sector banks showed an interest in infusing capital to reach the mandatory levels of capital to risk-weighted assets. Yet from the table above one can witness the grim picture of Equity Share Capital to Total Assets Ratio in the banking sector.

\subsection{Debt - Equity Ratio}

The Debt - Equity Ratio for a bank indicates the level to which a bank could borrow over long periods of time. The bank's equity plays the role of a headrest to protect depositors when the banks are in trouble.

Table 8

\begin{tabular}{ccc}
\hline Year & Public Sector Banks & Private Sector Banks \\
\hline 2011 & 0.00031 & 0.003599 \\
2012 & 0.000127 & 0.003022 \\
2013 & 0.000127 & 0.002856 \\
2014 & 0.00012 & 0.002398 \\
2015 & 0.002094 & 0.00197 \\
\hline
\end{tabular}

Table 10

\begin{tabular}{ccc}
\hline Year & Public Sector Banks & Private Sector Banks \\
\hline 2011 & 0.02137 & 250.2804 \\
2012 & 0.002926 & 299.562 \\
2013 & 0.004319 & 330.9683 \\
2014 & 0.005255 & 377.9827 \\
2015 & 0.707456 & 458.594 \\
\hline
\end{tabular}


The above table reveals that public sector banks are extremely and highly leveraged. But huge borrowings pose serious threat to solvency of Public Sector Banks. The Private Sector Banks maintained less than 1:1 debt-equity ratio. Though they are leveraged low, their solvency is not at stake.

\section{Liquidity, Solvency and OBS Items}

\subsection{Liquid Assets to OBS}

OBS items are those, not finding a place in the balance sheet that can transform themselves to liabilities on the adverse happening of an event. Though Capital Adequacy Ratio is maintained at $12 \%$ as per Basel-III norms, it may assure solvency but it may not satisfy liquidity. Hence it becomes inevitable to understand the relationship between the liquid cash and cash equivalent items to OBS items.

The above table evaluates the Liquid Assets to OBS Items Ratio of both the banks in detail. Despite having OBS items in higher proportion, the Public Sector Banks have maintained high ratios ranging from $10 \%$ to $16 \%$. Alternatively we see that Private Sector Banks have very ratios ranging between $2 \%$ to $4 \%$.

\subsection{Government Securities and OBS}

Every commercial bank invests in Government securities to comply with the norms of the RBI-monitored Statutory Liquidity Ratio (25\%) and they invest more than the required limit. Government securities are highly liquid securities with low returns. Though Public Sector Banks maintain SLR at high percentage of $40 \%$ till about the last decade, it has now slipped to around $28 \%$. The Public Sector Banks have to find the via media of managing liquidity to tackle NPAs on one side and to meet the need for further credit requirements on the other side.

Table 11

\begin{tabular}{ccc}
\hline Year & Private sector Banks & Public sector banks \\
\hline 2011 & 0.042976147 & 0.168678564 \\
2012 & 0.029575763 & 0.116336138 \\
2013 & 0.034479786 & 0.100429203 \\
2014 & 0.040660803 & 0.120202758 \\
2015 & 0.038124737 & 0.123241361 \\
\hline
\end{tabular}

http://www.informaticsjournals.com/index.php/sdmimd | Vol 8 | Issue 1 | March 2017
Table 12

\begin{tabular}{ccc}
\hline Year & Private Sector Banks & Public Sector Banks \\
\hline 2011 & 0.112127 & 0.490589 \\
2012 & 0.124517 & 0.470655 \\
2013 & 0.150107 & 0.457026 \\
2014 & 0.154373 & 0.128625 \\
2015 & 0.148432 & 0.481501 \\
\hline
\end{tabular}

The above table is reflective of the fact that Public Sector Banks are highly liquid and solvent enough to meet OBS items as and when they mature for settlement. Private Sector Banks have ratios ranging below $15 \%$, due to higher OBS values than those of Public Sector Banks. The Public Sector Banks revealed ratios as low as $12 \%$ in 2014, and yet they trodden up their investments in Government securities in 2015.

\subsection{Equity Share Capital to OBS}

Equity Share Capital is the last source of settlement against any liability of a bank. If the question of solvency arises, this ratio reveals the edge of the crisis in a much-more predictable way. Since the ownership patterns are different between Public and Private Sector Banks, this ratio will not be significantly valid:

Table 13

\begin{tabular}{ccc}
\hline Year & Private Sector Banks & Public Sector Banks \\
\hline 2011 & 0.002044618 & 0.008699679 \\
2012 & 0.001717284 & 0.006857473 \\
2013 & 0.001838219 & 0.006122523 \\
2014 & 0.001880271 & 0.005884759 \\
2015 & 0.001637883 & 0.004755228 \\
\hline
\end{tabular}

The above data explains that there is no significant difference in the ratios of both the banks. As far as the Public Sector Banks are concerned, the Government, being the major shareholder, is always willing to infuse funds towards Capital Adequacy Ratio-maintenance-a saviour towards implementing NPA provisions and so on. The Private Sector Banks, on the other hand depends on the RBI providers to bolt its liquidity ratios at acceptable levels. 


\section{Conclusion}

The liquidity position of Private and Public Sector Banks have been analysed in detail in this research paper. The findings of the study are as follows:

- The higher loan-deposits ratio of the Public Sector Banks results in higher illiquidity in the system. Private Sector Banks have lower loan-deposits ratio and are reasonably liquidity-centric.

- To meet demand deposits at any time, the Private Sector Banks enjoy a greater liquidity when compared against their Public Sector counterparts in the area of meeting demands for discharge of demand deposits.

- The Public Sector Banks have shown an ability to meet demand deposits in real time as they have a ratio of around 0.9:1.

- Both the Private and Public Sector Banks have lesser proportion of liquid assets to total assets, an indication that banks have lent heavily while investing likewise in more non-liquid assets. Hence the focus is on profitability.

- The Public and Private Sector Banks are not fully capable to meet liquidity contingency to meet both demand and time liabilities.

- Nearly $20 \%$ of total assets of both the sectorial banks are invested in government securities to meet not only the norms of the Statutory Liquidity Ratio but also towards enhancing profits or reducing losses when Non-performing assets are looming large.

- Private Sector Banks' Demand Deposits are higher in proportion to total deposits; hence their liquid assets to demand deposits are also high.

- CAR was showing decreasing trend for both the banks. But Public Sector Banks' decreasing CAR is dangerously below $11 \%$. But the trend of CAR of Private Sector Banks did not go down below the bench marks of Basel norms.

- If we take into account the solvency aspects, the Equity Capital alone cannot fulfil the solvency aspects of both the banks.

- Highly leveraged Private Sector Banks are at high risk zone of solvency, but this is offset by higher profitability.

- Public Sector Banks failed to generate leveragebenefits because of its low leverage ratios.
- Off- balance Sheet items pose very high risk among Private Sector Banks, but Public Sector Banks do not appear to give much credence to OBS items.

- The OBS items of Private Sector Banks are very high compared to those of Public Sector Banks; Government securities are safe cushion to face OBS related risks for Public Sector Banks.

- Poor Equity Capital to OBS Items ratio gives a grim picture of long term solvency of both sectors of the commercial banks.

It must be stated that the Private Sector Banks are provided with the liquidity support from the Reserve Bank of India. Basically no bank will be left in lurch in tackling its liquidity woes. Public Sector Banks are pampered financial intermediaries used to keep the economic system intact. The tacit understanding between RBI, Government of India and Commercial Banks, in general and Public Sector Banks in particular ensured that the systemic risk was kept at bay. Solvency of Commercial Banks again is being monitored by the Banking Regulator, RBI, with greater vigil. This makes banking system near-fool proof, and geared to face the global economic tremors with lesser impact. Insulation against economic shocks is the time-tested objective of the banking system in India in managing the risks.

\section{References}

Bharathi, U., \& Singh S. (2014). Liquidity and profitability analysis of commercial banks in India- A comparative study. Global Journal of Enterprise Information system, 6(4).

Choi, D. B., \& Zhou L. (2014). The liquidity stress ratio: Measuring liquidity mismatch on banks balance sheet. Liberty Street Economics.

George, A. S. (2016). Productive efficency service quality and profitability: A comparative analysis of foreign and private banks in India. International Journal of productivity and Quality Management. Retrieved from: https://doi. org/10.1504/IJPQM.2016.077780

Goel, C., \& Rekhi, C. B. (2013). A comparative study on the performance of selected public and private sector banks in India. 2013 Jul. Journal of Business Management and Social Sciences Research, 2(7).

Makkar, A., \& Singh, S. (2013). Analysis of the financial performance of Indian commercial banks - A comparative study. May 2013Volume 7, Issue 5. 
Narashiman, P., Venkatesh, K. A. (2016). OBS and profitability of foreign banks in India. Shanlax International Journal of Management, 3(2), 347-353.

Parameshwaran, R., \& Natarajan, S. (2007) Indian Banking. S. Chand Ltd.

Ramanarayanan, A. S., \& Unas, A. W. (2014). Liquidity management in financial service sectors -with special reference to public sector banks of India. International Journal of Emerging Research in Management and Technology, 3(8).

Reports on trend and progress of banking in India. Available from: www.businesstoday.com Available from: www. businessline.com
Singh, A., \& Sharma, A. K. (2016). An empirical analysis of macro-economic and bank specific factors affecting liquidity of Indian banks. Future Business Journal, (1). Retrieved from: https://doi.org/10.1016/j.fbj.2016.01.001 Statistical tables. Avaialble from: www.rbi.org.in Teixeria, D. (2013). Off-balance sheet items in european banking: a panel data econometric model on risk and liquidity. Respositrio Aberto da Universidadi de Porto. 
